\title{
Do assédio moral à violência interpessoal: Relatos sobre uma empresa júnior
}

\author{
From moral harassment to interpersonal violence: Reports on a junior \\ enterprise
}

\author{
Renata de Almeida Bicalho Pinto ${ }^{1}$ \\ Ana Paula Paes de Paula ${ }^{2}$
}

\section{Resumo}

O objetivo deste artigo é analisar a violência interpessoal vivenciada por sujeitos que atuam ou atuaram profissionalmente em uma empresa júnior (EJ). Para tanto, desenvolvemos um referencial teórico que apresenta e pondera sobre a teoria relativa ao assédio moral no trabalho. De modo sucinto, o assédio moral geralmente é caracterizado, nos Estudos Organizacionais, como condutas hostis, impróprias, repetitivas e prolongadas por meio de posturas, palavras, gestos e/ou situações humilhantes que envolvem o trabalhador, ou um grupo, durante a jornada de trabalho. Neste artigo, questionamos o conceito de assédio moral, que é intimamente relacionado à intencionalidade dos sujeitos, e, em contrapartida, propomos o conceito de violência interpessoal, isto é, o ato de agredir o sujeito física e/ou discursivamente e/ou por atitudes e/ou comportamentos prejudiciais, sejam propositais ou não. Em seguida, analisamos alguns relatos de violência interpessoal experienciadas por atuais ou ex-empresários juniores à luz desse conceito; realizamos uma pesquisa empírica de cunho qualitativo, na qual utilizamos a metodologia da história oral e analisamos os dados de acordo com a técnica hermenêutica/dialética. Constatamos que os tipos de violência relatados são, na maioria dos casos, naturalizados pelas próprias vítimas e pelo corpo social em decorrência de uma práxis tida como necessária para a incorporação do sujeito. Destacamos, ainda, o nítido imbricamento das categorias violência interpessoal e violência simbólica.

Palavras-chave: Assédio moral no trabalho. Violência simbólica. Violência interpessoal.

\section{Abstract}

This article aims to analyze the interpersonal violence experienced by subjects who work or worked in a junior enterprise (JE). For this, we have developed a theoretical framework which presents and thinks through the theory related to workplace moral harassment. Succinctly, moral harassment is usually characterized, in the Organizational Studies, as hostile, inappropriate, repetitive, and prolonged behaviors exercised through attitudes, words, gestures, and/or humiliating situations involving the worker, or a group, during the work day. In this article, we discuss the concept of moral harassment, which is closely related to the subject's intentionality, and, on the other hand, we propose the concept of interpersonal violence, that is, the act of assaulting the subject in a physical and/or discursive way and/or through actions and/or harmful attitudes, either intentionally or not. Then, we analyze some reports of interpersonal violence experienced by current or former junior entrepreneurs under the light of this concept; we conducted an empirical survey with a qualitative approach, where we used the oral history methodology and analyzed data according to the hermeneutic/dialectic technique. We found out that the types of violence reported are, in most cases, naturalized by the

Artigo submetido em 10 de março de 2013 e aceito para publicação em 09 de setembro de 2013.

1 Doutoranda em Administração pelo Centro de Pós-Graduação e Pesquisas em Administração/FACE-UFMG; Professora Assistente da Universidade Federal de Juiz de Fora. Endereço: Campus Universitário s/nº, Martelos CEP 36036-900, Juiz de Fora - MG, Brasil. E-mail: rabicalho@yahoo.com.br

${ }^{2}$ Doutora em Ciências Sociais pelo Instituto de Filosofia e Ciências Humanas/UNICAMP; Professora Titular da Universidade Federal de Minas Gerais. Endereço: Av. Antônio Carlos, 6627 - sala 4033 - FACE-UFMG, Pampulha, CEP 31270-010, Belo Horizonte - GM, Brasil. E-mail: appaula@face.ufmg.br 
victims themselves and the social body as the result of a kind of praxis considered necessary for incorporating the subject. We also highlight the clear overlapping of the categories interpersonal violence and symbolic violence.

Keywords: Workplace moral harassment. Symbolic violence. Interpersonal violence.

\section{Introdução}

O cotidiano organizacional hodierno é, normalmente, competitivo e conflituoso, o que tende a impactar nas relações que se estabelecem nesse espaço, propiciando perseguições e manifestações diversas de violência. Entretanto, tendemos, muitas vezes, a naturalizar ou mesmo banalizar tais ocorrências sob o pretexto de que um ambiente em tais moldes estimula a superação pessoal e leva a um desempenho geral melhor. Como Freitas (2007, p. 278) afirma, “[...] estamos acostumados a aceitar a violência como algo normal, como parte do cotidiano e da paisagem, como se os seus alvos fossem certos e apenas a escolha aleatória”.

Nesse tipo de cenário, conflituoso e competitivo, no qual, em geral, os resultados são priorizados em detrimento das relações e das questões morais, ocorrem com frequência casos de violência e assédio moral. E "[...] não é incomum que o assédio moral surja de forma insignificante confundindo-se com uma brincadeira de mau gosto, o que dificulta a sua consideração séria pela vítima e a sua formalização como um problema organizacional" (FREITAS, HELOANI e BARRETO, 2008, p. 26). Tantas vezes o assédio moral é encoberto por uma pretensa cobrança por desempenho ou é entendido como um aspecto jocoso típico das interações que, devido à sua persistência, acaba por violentar o indivíduo. "Tais ações podem ocorrer de forma direta ou indireta, por ação ou omissão, por gestos, insinuações, zombaria, sarcasmo, ironias, hostilidade, maledicência, pela atitude de desprezo e/ou por tornar insignificante a vítima, cuja existência passa a ser ignorada" (PELI e TEIXEIRA, 2006, p. 27). As consequências do assédio moral, que envolve constantes humilhações e assolamentos, vão desde a demissão da vítima até seu adoecimento físico e mental, com repercussões negativas para as organizações e o Estado devido ao afastamento do sujeito de seu trabalho (OLIVEIRA, 2006). Este artigo teórico/empírico insere-se nesse debate e seu propósito é analisar criticamente a teoria sobre o assédio moral no trabalho, bem como defender um novo conceito para o estudo dessa temática - a violência interpessoal. O objetivo é ponderar sobre determinada violência interpessoal vivenciada por sujeitos que atuam, ou atuaram, profissionalmente em uma empresa júnior, a qual designamos EJ. Destacamos, desde já, que a pesquisa também abarcou a violência simbólica, que, apesar de não serem alvo deste artigo, estão intimamente relacionadas à violência interpessoal evidenciada.

Para tanto, sintetizamos, no tópico seguinte, o debate e a conceituação que circundam o assédio moral no trabalho. Em seguida, tecemos críticas à acepção de assédio comumente utilizada na literatura, apresentando um novo conceito, a violência interpessoal, que não determina, como caracterizadora do assédio, a prerrogativa da recursividade e também não estabelece a necessidade de o assediador deter uma patologia, premeditar ou ter plena consciência das violações que põe em prática. Além disso, esse conceito não limita os impactos do assédio à esfera do trabalho e não coaduna com a posição passiva do assediado. Delimitamos, então, a metodologia de pesquisa e apresentamos relatos de violência vivenciados por integrantes ou exintegrantes da EJ à luz desse conceito. Por fim, apresentamos nossas considerações finais.

\section{Assédio moral no trabalho}

A violência sob a perspectiva do assédio moral foi abordada, primeiramente, pelo psicólogo alemão Heinz Leymann por meio do termo mobbing ${ }^{3}$. Entretanto, ele não foi o pioneiro na utilização desse conceito.

\footnotetext{
3 Hirigoyen (2003; 2005) adota como sinônimos os termos mobbing e assédio moral. Aderimos à sua designação. Assim, quando Leymann (1996) expressa ou nos referimos à sua obra utilizando o termo mobbing podemos ler, sem prejuízo ao conteúdo, assédio moral.
} 
Leymann (1996) faz alusão ao estudo do etnólogo Konrad Lorenz como pioneiro no estudo do mobbing, apesar de referir-se a outra instância de investigação. Konrad Lorenz empregou o termo mobbing para caracterizar um ataque procedente de um grupo de animais menores ameaçando um animal maior e sozinho. Anos depois, o mesmo conceito foi empregado por Peter-Paul Heinemann para o estudo de comportamentos destrutivos empregados por pequenos grupos de crianças e dirigidos contra (na maioria das vezes) uma criança sozinha (LEYMANN, 1996).

Leymann (1996, p. 167, tradução nossa) relata que, então, “[...] seguindo essa tradição, tomei emprestado o termo mobbing no início dos anos 1980, quando encontrei um tipo similar de comportamento no ambiente de trabalho" na Suécia. A apropriação desse conceito não se deu sem uma reflexão e adequação paralela, uma vez que "[...] o bullying na escola é fortemente caracterizado por certos atos de agressividade física. Em contraste, é muito raro encontrar violência física no mobbing, referente ao trabalho" (LEYMANN, 1996, p. 167, tradução nossa). Destarte, o autor propõe empregar o termo bullying para interações violentas ocorridas entre crianças e adolescentes, na escola, e preservar o termo mobbing para relacionamentos violentos entre adultos.

A partir da adoção do termo mobbing at work, Leymann (1996, p. 165, tradução nossa) afirma que o conceito expressa um conflito no qual

[...] a vítima é submetida a um processo sistemático e estigmatizante e há usurpação de seus direitos civis. Se isso durar anos, pode, por fim, levar à expulsão do mercado de trabalho quando o indivíduo em questão for incapaz de encontrar emprego devido ao dano psicológico sofrido.

Nesse sentido, o autor estabelece critérios para detectar o assédio moral no trabalho.

Terror psicológico ou mobbing na vida do trabalho envolve a comunicação hostil e não ética que é dirigida de forma sistemática por um ou alguns indivíduos principalmente em direção a um indivíduo que, devido ao mobbing, é impelido a uma posição de impotência e indefesa, sendo mantido ali por meio da continuidade das atividades de mobbing. Essas ações ocorrem em bases muito frequentes (definição estatística: ao menos 1 vez por semana) e por um longo período de tempo (definição estatística: ao menos 6 meses de duração). Por conta da alta frequência e longa duração do comportamento hostil, esses maus-tratos resultam em considerável sofrimento psicológico, psicossomático e social. A definição exclui conflitos temporários e focados no período em que a situação psicossocial teve início para resultar em condições patológicas psiquiátricas e psicossomáticas. Em outras palavras, a distinção entre conflito e mobbing não foca o que é feito ou como isso é feito, mas na frequência e duração do que é feito. [...] A definição científica do termo mobbing se refere a uma interação social por meio da qual um indivíduo (raramente mais de um) é atacado por um ou mais (raramente mais de quatro) indivíduos quase diariamente e por períodos de muitos meses, levando a pessoa a uma condição quase sem defesa, com riscos potencialmente altos de expulsão (LEYMANN, 1996, p. 168, tradução nossa).

Os trabalhos de Heinz Leymann influenciaram Marie-France Hirigoyen, que, durante a década de 1990, passou a desenvolver estudos na França tratando do assédio moral no trabalho, bem como a repensar e rever a concepção apregoada por Heinz Leymann. O caráter ordinário com que se desenvolve o assédio moral nas organizações, associado à potencialidade dessas ações rotineiras e veladas tornarem-se devastadoras para a saúde psicológica e a vida profissional das vítimas, foi um dos motivadores iniciais dessa autora. A ocorrência, em sua prática clínica, de casos que retratavam tal violência insidiosa possibilitou a ela vislumbrar o reflexo da atuação de um sujeito perverso nas várias instâncias de relacionamento social (HIRIGOYEN, 2003). Inclusive, o primeiro livro de Marie-France Hirigoyen - Assédio moral: a violência perversa no cotidiano - discorre sobre o assédio moral em vários contextos das relações humanas: casamento, família e trabalho; já seu segundo livro - Mal-estar no trabalho: redefinindo o assédio moral - trata exclusivamente da violência circunscrita à esfera do trabalho. 
No primeiro livro, como dito, Hirigoyen (2003) introduz a discussão acerca do assédio moral em vários contextos das relações humanas; em especial, o "assédio na empresa" é descrito pela autora como:

[...] qualquer conduta abusiva manifestando-se[,] sobretudo[,] por comportamentos, palavras, atos, gestos, escritos que possam trazer dano à personalidade, à dignidade ou à integridade física ou psíquica de uma pessoa, pôr em risco seu emprego ou degradar o ambiente de trabalho (HIRIGOYEN, 2003, p. 65).

Nesse mesmo livro, Hirigoyen (2003) aborda como a manifestação dessa violência se realiza nas instâncias já enunciadas, como se caracterizam os envolvidos nela e como se desenvolvem as relações marcadas pela perversidade de um indivíduo, o assediador, e, ainda, quais são as consequências psicossociais do assédio para suas vítimas. O livro termina com a apresentação de capítulos propositivos com alternativas para a superação da condição de opressão estabelecida.

No segundo livro, o enfoque se restringe ao âmbito do trabalho, e o conceito de assédio moral anteriormente estabelecido é revisto pela autora por considerar urgente uma definição que demarque seu entendimento e que, assim, impossibilite a utilização desse termo de maneira abusiva ou errônea. O intento de Hirigoyen (2005) é, notoriamente, estabelecer as bases para a criminalização das práticas de assédio moral e para o tratamento psiquiátrico das vítimas de tal violência. Para tanto, a autora restringe ainda mais a concepção de assédio, com vistas a possibilitar aos clínicos gerais e psiquiatras "[...] identificar de forma adequada a especificidade desse tipo de violência e os respectivos sintomas decorrentes [...]", além de prover aos juristas "[...] uma definição, livre tanto quanto possível de qualquer subjetividade[,] para que sejam classificados penalmente esses processos violentos" (HIRIGOYEN, 2005, p. 16). Desse modo,

[...] o assédio moral no trabalho é definido como qualquer conduta abusiva (gesto, palavra, comportamento, atitude...) que atente, por sua repetição ou sistematização, contra a dignidade ou integridade psíquica ou física de uma pessoa, ameaçando seu emprego ou degradando o clima de trabalho (HIRIGOYEN, 2005, p. 17).

Ela estabelece, nessa mesma obra, que qualquer definição de assédio moral precisa caracterizá-lo como “[...] uma violência não reptícia, não assinalável, mas que, no entanto, é muito destrutiva" (HIRIGOYEN, 2005, p. 17), a qual é mais direta, verbal ou física nos setores de base das organizações e mais sofisticada, perversa e difícil de perceber à medida que as relações se estabelecem em porções mais elevadas da pirâmide hierárquica. Hirigoyen (2005) preocupa-se, também, com a ilustração, por meio de casos empíricos, das relações que podem ser designadas pela ocorrência do assédio moral e pelo estabelecimento de proposições para a prevenção do assédio moral no local de trabalho, apregoando a ética e a responsabilidade individual como fundamentos.

Julgamos relevante, neste ponto, salientar uma ruptura que Hirigoyen (2005, p. 30) estabelece com a concepção de assédio moral defendida por Leymann; para a autora, "[...] o assédio moral caracteriza-se antes de tudo pela repetição", contudo critica a frequência (ao menos 1 vez por semana) e o período mínimo (6 meses) estabelecidos por Leymann para caracterizar um assédio moral. "Fixar deste modo um patamar limite parece excessivo, pois a gravidade do assédio não depende somente da duração, mas também da violência da agressão. Algumas atitudes especialmente humilhantes podem destruir alguém em menos de seis meses!" (HIRIGOYEN, 2005, p. 30).

Alguns pontos se destacam na caracterização que Hirigoyen $(2003$; 2005) estabelece para o processo de assédio moral. Além da questão da recursividade, a autora enfatiza em vários momentos de seus livros a intencionalidade como qualificativo da existência do assédio moral, o que justifica da seguinte maneira: “[...] sempre que se fala de agressão psicológica, não se deve excluir a questão da intencionalidade, pois o caráter intencional de um traumatismo agrava o impacto da agressão" (HIRIGOYEN, 2005, p. 63). A intencionalidade dos atos torna-se mister, na concepção da autora, para que se diferencie adequadamente assédio moral de más condições de trabalho, porquanto, de acordo com Hirigoyen (2005, p. 34-35), "[...] o 
assédio moral é um abuso e não pode ser confundido com decisões legítimas, que dizem respeito à organização do trabalho [...] É natural que todo trabalho apresente um grau de imposição e dependência".

O assédio moral é interpretado como um processo perverso por possibilitar a manipulação e agressão de um, o assediado, em prol da demarcação do poder e da obtenção de vantagens de outro, o assediador. Hirigoyen (2003; 2005) atribui, em especial, ao último uma personalidade do tipo perverso/narcísico, em termos psicanalíticos ${ }^{4}$. Enfatizamos que tal seja um pré-requisito para a caracterização desses indivíduos, os quais se valem de um contexto propício, "[...] que começa com um abuso de poder, prossegue com um abuso narcísico - no sentido de que o outro perde totalmente a autoestima - e pode chegar[,] por vezes[,] a um abuso sexual" (HIRIGOYEN, 2003, p. 16). No entanto, os demais envolvidos nesse processo de violência não são tidos como inocentes ou passivos, mas, sim, como cúmplices, pois "[...] mesmo que a pessoa mais diabólica seja necessariamente a que dá a saída para o assédio moral, isso não deve tirar a responsabilidade dos outros, dos que foram omissos" (HIRIGOYEN, 2005, p. 65).

A relação em que o assédio moral se manifesta é discriminada, ainda, pela assimetria, real ou suposta, entre as pessoas envolvidas. "Aquele que põe em ação a violência define-se como existencialmente superior ao outro, o que é[,] em geral[,] aceito por aquele que recebe a violência" (HIRIGOYEN, 2005, p. 135). Uma relação distinta de um simples conflito, pois nela se estabelece a sujeição de um dos envolvidos, "[...] uma relação dominante-dominado, na qual aquele que comanda o jogo procura submeter o outro até fazê-lo perder a identidade" (HIRIGOYEN, 2005, p. 27-28). Nesses arrolamentos, os oprimidos são considerados impotentes, pois "[...] é raro terem consciência de que existe essa temível violência subterrânea, e que ousem queixar-se dela. [...] a vítima, mesmo reconhecendo seu sofrimento, não ousa verdadeiramente imaginar que tenha havido violência e agressão" (HIRIGOYEN, 2003, p. 16).

Nesse esteio, percebemos, enfim, que mesmo sendo uma violência sub-reptícia - em outros termos, praticada às ocultas -, o assédio moral é real, tal como suas consequências para a saúde das vítimas, podendo implicar tanto prejuízos físicos quanto psíquicos e, no extremo, o suicídio da vítima.

Reiteramos que, em seu primeiro livro, Marie-France Hirigoyen (2003) discorre sobre vários âmbitos da vida do sujeito nos quais o assédio moral pode estabelecer-se e apresentar impactos. Já na segunda obra, Hirigoyen (2005) focaliza unicamente o aspecto profissional, nas vivências e implicações relacionadas à esfera do trabalho, em detrimento dos demais.

A obra de Marie-France Hirigoyen e a discussão sobre assédio moral repercutiram em diversas instâncias sociais e em meios de comunicação, acadêmicos e populares, após a tradução de seu primeiro livro para o português, em 2001 (FREITAS, 2007). Especificamente no âmbito dos Estudos Organizacionais, destacaram-se três autores brasileiros na discussão dessa temática: Maria Ester de Freitas, Roberto Heloani e Margarida Barreto, respectivamente das áreas de Administração de Empresas, Educação e Psicologia Social.

Em recente obra publicada em parceria - Assédio moral no trabalho -, Freitas, Heloani e Barreto (2008) elaboram um retrospecto das discussões iniciadas por Marie-France Hirigoyen e por eles mesmos desenvolvidas de acordo com as particularidades brasileiras. Nesse livro, Freitas, Heloani e Barreto (2008) caracterizam a organização contemporânea do trabalho, inclusive como estimuladora da violência; discutem o assédio moral e os reflexos de sua perpetração no ambiente de trabalho, na empresa e nos indivíduos; e analisam as formas de punição e prevenção de episódios abarcando essa manifestação de violência. Os autores adotam integralmente o conceito de assédio moral estabelecido por Hirigoyen (2005). Destacamos nessa obra a correlação entre os processos de discriminação e a ocorrência do assédio moral e a declaração por parte dos autores de que "[...] nossas pesquisas em todo o território nacional nos autorizam a afirmar que esta prática cruel [o assédio moral] está disseminada em todas as organizações, quer públicas ou privadas" (FREITAS, HELOANI e BARRETO,2008, p. 105).

\footnotetext{
${ }^{4}$ Para maiores detalhes sobre a personalidade perversa/narcísica do assediador, vide o capítulo 6 (O agressor) de Hirigoyen (2003)
} 
Ademais, nas várias obras nas quais os autores trataram da temática "assédio moral no trabalho" (FREITAS, 2001; 2007; FREITAS, HELOANI e BARRETO, 2008; HELOANI, 2004), eles corroboram a necessidade de investigar esse tipo de violência com base em sua frequência, por entenderem que:

[...] não é incomum que o assédio moral surja de forma insignificante[,] confundindo-se com uma brincadeira de mau gosto, o que dificulta a sua consideração séria pela vítima e a sua formalização como um problema organizacional. Como a sua característica principal é a repetição, é somente depois de ser regularmente acuada que a vítima percebe que os ataques se multiplicaram e o seu estado de inferioridade ou fragilidade torna mais difícil a sua reação (FREITAS, HELOANI e BARRETO, 2008, p. 26).

Os autores contribuíram, ainda, resumindo outras características do assédio moral explicitadas por Hirigoyen (2003; 2005), tais como sua ocorrência em sentidos diversos: entre pares, de superior a subordinado e de subordinado a superior; e sua classificação em 4 grandes categorias: deterioração proposital das condições de trabalho; isolamento e recusa de comunicação; atentado contra a dignidade; e violência verbal, física ou sexual.

A influência de Marie-France Hirigoyen não se limitou ao Brasil. Sua acepção sobre o assédio moral inspira a maior parte dos autores que dissertam sobre tal temática. Destarte, é inegável a importância de sua obra, visto que foi uma das precursoras do estudo da violência nas organizações. Contudo, apresentamos algumas ressalvas às suas ideias no tópico a seguir.

\section{Do assédio moral à violência interpessoal}

Seguindo as influências de Hirigoyen (2003; 2005), o assédio moral geralmente é caracterizado, nos Estudos Organizacionais, como: condutas hostis, impróprias, repetitivas e prolongadas por meio de comportamentos, palavras, gestos e/ou situações humilhantes com o trabalhador, ou com um grupo, durante a jornada de trabalho. Tal definição remete à segunda concepção proposta por Hirigoyen (2005, p. 17), a qual retomamos:

O assédio moral no trabalho é definido como qualquer conduta abusiva (gesto, palavra, comportamento, atitude...) que atente, por sua repetição ou sistematização, contra a dignidade ou integridade psíquica ou física de uma pessoa, ameaçando seu emprego ou degradando o clima de trabalho.

A autora se propôs a rever o conceito inicialmente desenvolvido (HIRIGOYEN, 2003) por conta de uma série de interpretações inadequadas que possibilitaram a caracterização de qualquer tipo de agressão como um assédio moral, o que propiciaria sua banalização com base na desqualificação de seu significado. Essa mesma preocupação, com uma significação clara e com a possibilidade de generalização do termo, é constante entre os pesquisadores de assédio moral, seja na linha de estudos da Psicossociologia, do Direito ou das Relações de Trabalho, como já apontamos. Contudo, pouca atenção tem sido dada à percepção dos sujeitos quanto àquilo que eles designam ou relatam desapercebidamente como violência ocorrida em seu ambiente de trabalho. Quando falamos de violência relatada desapercebidamente estamos nos referindo a situações ou contextos descritos pelos sujeitos como naturais ou sem apontamentos explícitos sobre a ocorrência de violência que, no entanto, podem ser analisados como reflexos da atuação de um poder simbólico, o que caracterizaria a ação de uma violência simbólica. Ressaltamos, nesse ponto, que a pesquisa da qual este artigo é fruto também abarcou a violência simbólica, que, apesar de não ser alvo deste artigo, está intimamente relacionada à violência interpessoal evidenciada. Desenvolvemos tal relação em maior detalhe em nossas considerações finais. 
Questionamos, nesse sentido, a necessidade da certeza quanto à intencionalidade do sujeito, bem como uma recursividade para caracterizar o assédio moral. Como já apontamos em trabalhos anteriores uma violação pontual, seja ela física ou discursiva, pode impactar de maneira mais perniciosa o sujeito do que pequenas violências sucessivas, cabendo ao próprio avaliar aquilo que mais o vitimiza, ou seja, o faz sentir-se violentado". Hirigoyen (2005), buscando superar o conceito de mobbing defendido por Leymann, explicita que a violência infligida não depende somente de sua duração, mas, também, de sua agressão. Consideramos que a recursividade que a autora defende está associada ao arrolamento de sua obra nos campos jurídico/penal e psiquiátrico, que necessitam de parâmetros objetivos para a caracterização de um crime e de uma doença. No entanto, destacamos a limitação do conceito de Hirigoyen (2005), que restringe o que se entende por assédio moral no trabalho, negando outras vivências e análises que não se adequem a esse conceito. A limitação de sua leitura não finda nesse ponto. Assim notamos que os impactos do assédio moral são restringidos, na grande maioria dos estudos sobre assédio moral, à degradação das relações de trabalho e dos demais elementos circunscritos à organização e, quando se trata dos impactos na saúde do trabalhador, associa-se isso ao comprometimento de seu desempenho, que pode levar a um menor rendimento, à perda de possíveis oportunidades de ascensão profissional e à necessidade de ele se licenciar ou abandonar o emprego. Tal leitura menospreza a vida do sujeito além das fronteiras institucionais, desconsidera que as relações marcadas pela violência que o sujeito vivencia no ambiente profissional podem refletir-se em inimagináveis outros aspectos da vida desse indivíduo. Aliás, ousamos afirmar que a perspectiva que norteia tais análises parte do ponto de vista da própria gestão, isto é, o foco não é necessariamente o sujeito violentado, mas as consequências da violência para a organização. Um exemplo que ilustra o impacto da vivência do ambiente de trabalho na vida do sujeito, em sentido pleno, é o caso relatado por Dejours (1996), no qual a realidade opressora onde um trabalhador desenvolvia suas atividades repercutiu claramente em suas relações sociais, uma vez que ele passou a evitar seus familiares e conhecidos, além de agredir seus filhos para afastá-los.

Freitas (2007), assim como Hirigoyen (2005), focaliza o âmbito do trabalho para discutir a questão do assédio moral, como ilustra a seguinte afirmação:

[...] ele acontece no ambiente de trabalho, entre atores organizacionais, sob condições organizacionais e com prerrogativas organizacionais; se existe um componente individual, existem vários outros componentes estritamente organizacionais, que são parte do próprio processo de trabalho e das estruturas que lhe sustentam (FREITAS, 2007, p. 287).

Contudo, ao analisar os impactos do assédio moral, Freitas (2007) não se limita à esfera organizacional, como faz Hirigoyen (2005), abarcando, também, as repercussões na família dos assediados. Tal posicionamento é depreendido, por exemplo, da subsequente passagem: “[...] os indivíduos vitimizados podem desenvolver problemas que provocam desestruturação familiar, tais como alcoolismo, depressão, divórcio, abandono, suicídios, indigência" (FREITAS, 2007, p. 289).

Outros pontos são passíveis de crítica na concepção de assédio estabelecida por Hirigoyen (2005), tais como a qualificação do assediador, necessariamente, como um indivíduo que apresenta a patologia da perversão narcísica, a qual se manifesta no sujeito como um sentimento de grandeza, um egocentrismo descomedido e uma completa falta de empatia por outrem, acompanhados de uma inveja aguda daqueles que possuem algo que ele não tem ou daqueles que sentem prazer com a própria vida; de mais a mais, falta a ele densidade afetiva e ele é incapaz de entender as emoções alheias (HIRIGOYEN, 2003). Será, realmente, que todo assediador ou violentador tem esse tipo de patologia? Preferimos considerar que, mesmo quando a violência é deliberada, o que em nosso ponto de vista não é uma regra, o sujeito pode agir em decorrência de algum desvio moral motivado por certo interesse, o que não caracterizaria seu ser, mas seria reflexo de uma escolha diante daquela dada circunstância estruturada e permitida, inclusive, pela própria organização. Isso é corroborado, contraditoriamente, por Hirigoyen (2005, p. 350), ao assegurar que: "[...] todos nós somos 'assediadores' potenciais, eventuais futuras vítimas de superiores hierárquicos ou subordinados de alguém"; sendo assim, seríamos todos potenciais detentores da patologia da perversão narcísica? 
O fundamento de deliberação da ação que caracteriza o assédio moral também é um eixo crucial e obscuro na obra de Marie-France Hirigoyen. Em uma das primeiras páginas de seu segundo livro, Hirigoyen (2005, p. 17) afirma que "[...] um assédio extremamente destruidor pode ocorrer sem que inicialmente houvesse qualquer intenção nociva”. Contudo em inúmeras outras passagens do mesmo livro a autora defende a premeditação como algo inerente; por exemplo:

Pode-se[,] então[,] falar de assédio moral, pois se trata efetivamente de uma ação deliberada para se livrar de uma pessoa, humilhá-la, rebaixá-la, por puro sadismo (HIRIGOYEN, 2005, p. 31, grifo nosso);

Frequentemente, é muito difícil a distinção entre assédio moral e más condições de trabalho. É nes[s]e caso que a noção de intencionalidade adquire toda a sua importância (HIRIGOYEN, 2005, p. 33, grifo nosso);

Enquanto um conflito é o encontro de elementos ou de sentimentos contrários que se opõem, no assédio moral, como em toda agressão, existe a vontade de ferir o outro (HIRIGOYEN, 2005, p. 274, grifo nosso).

Julgamos que a análise da ocorrência de um assédio não pode ser limitada pela explicitação de que o violentador agiu intencionalmente, tendo em vista que as relações interpessoais se estabelecem tantas vezes a partir de bases instáveis e abstrusas, nas quais os sujeitos estão vulneráveis a ações e pronunciamentos que divergem desde a intenção até o resultado produzido, podendo violentar outrem mesmo não sendo esse o desejo primário. Além disso, a violência não necessariamente se restringe à esfera da interação explícita, como é o caso da violência simbólica, podendo envolver o plano simbólico, inclusiva ou complementarmente.

Além disso, incomoda-nos a posição passiva que Hirigoyen $(2003 ; 2005)$ atribui ao sujeito assediado. A nosso ver, a autora, ao analisar as relações marcadas pelo assédio moral por meio da dicotomia dominador/dominado, denota uma leitura pessimista do homem ou estigmatiza os vitimizados como apáticos, seja por natureza ou por força das circunstâncias. Vislumbramos em sua descrição um indivíduo incapaz de apreender o que ocorre ao seu redor e consigo, bem como de superar a dominação a que ele está submetido, uma vez que sua identidade foi necessariamente dilacerada pela recorrente violência experienciada.

Outra asseveração discutível é a seguinte: “[...] é natural que todo trabalho apresente um grau de imposição e dependência” (HIRIGOYEN, 2005, p. 34-35). Vejamos as palavras de La Boétie (1986, p. 43).

Diga-se, pois, que acaba por ser natural tudo o que o homem obtém pela educação e pelo costume; mas da essência da sua natureza é o que lhe vem da mesma natureza pura e não alterada; assim, a primeira razão da servidão voluntária é o hábito.

Acrescentaríamos, ainda, que de tal hábito advém a naturalização da exploração presente nas relações sociais de produção. Naturalização esta expressa nas citadas palavras de Hirigoyen (2005).

Uma crítica também necessária dirige-se a Leymann (1996), pois, para ele, uma agressão dirigida a outrem, caso seja fruto do estresse ou do destempero emocional momentâneo e seguida de arrependimento e pedido de desculpa, não caracterizaria um assédio moral (mobbing at work, em seus termos). Sua argumentação indicaria que o pedido de desculpas minimiza ou exclui o assédio infringido? Ou que uma instabilidade emocional breve justificaria e abrandaria a violência ocorrida? Entendemos que tais questões se fundamentam em uma flexibilidade moral controversa, tendo em vista que as implicações da violência tantas vezes não podem ser ou se deseja que não sejam eliminadas graças a escusas ou duvidosas alegações.

Outro ponto passível de revisão é a restrição dos estudos sobre assédio em relação à violência interpessoal, desconsiderando os aspectos simbólicos da organização e da sociedade como um todo presentes nas relações 
e podendo ser utilizados para violentar o sujeito. Catley (2005) já apontou essa limitação e enfatizou, inclusive, o apego da academia pelas agressões, defendendo uma leitura atenta à violência estrutural, que, para ele, caracteriza o cotidiano dos ambientes de trabalho contemporâneos.

Depois das considerações apresentadas, não poderíamos nos restringir ao conceito inicial, proposto por Hirigoyen (2003; 2005), de assédio moral. Desse modo, desenvolvemos um conceito próprio para tal manifestação da violência, segundo o qual: a violência interpessoal advém do ato de agredir o sujeito física e/ou discursivamente e/ou por atitudes e/ou comportamentos ${ }^{5}$ prejudiciais, sejam estes propositais $^{6}$ ou não. Tal manifestação de violência se desenvolve, necessariamente, durante a interconexão de duas ou mais pessoas, pontual ou recursivamente, no ambiente de trabalho, revelando-se como violência física, discursiva, fruto de atitudes ou derivada de comportamentos. Os impactos de tal violência são: a degradação de aspectos e/ou relações atinentes ao trabalho, à vida pessoal e/ou às relações em geral; bem como a manifestação de doenças psicopatológicas.

Importante nos parece esclarecer o que denominamos violência física, discursiva e proveniente de atitudes e de comportamentos. Por violência física entendemos violações do corpo humano, por meio do exercício de força física que implique lesão ou cause dano a um sujeito. Por violência discursiva, produções discursivas que causam prejuízo por meio da linguagem dirigida a um sujeito, seja pelo desmantelamento de sua identidade, imputando-lhe um sentimento de inferioridade, pela opressão ou por outra forma de ataque, injúria, mágoa ou avaria subjetiva, em consenso com Catley (2003). Já por violência causada por comportamentos concebemos os prejuízos originários de um conjunto das reações que se pode observar em um indivíduo e por agressões motivadas por atitudes afrontas advindas de predisposições de outrem para reagir de maneira negativa.

Optamos pelo conceito de violência interpessoal tendo em vista que este não restringe a análise das percepções do sujeito à prerrogativa da recursividade nem desconsidera os impactos da violência infligida nos vários âmbitos da vida do sujeito, ou seja, não reduz as consequências aos reflexos percebidos no ambiente de trabalho. Adicionalmente, esse conceito não é adstrito, como o de Hirigoyen (2003; 2005), pela necessidade de o assediador deter a patologia da perversão narcísica e de ele estar consciente e agir deliberadamente quando violenta outrem.

Vale notar, ainda, que não podemos nos restringir ao conceito de violência interpessoal já apresentado. Consideramos que o estudo da violência não pode se limitar à esfera das interações diretas entre os indivíduos, mas que é necessária uma abordagem complementar por meio do estudo da violência simbólica, que envolve a naturalização da violência. Destarte, entendemos, a partir de pesquisas anteriores, que a violência simbólica refere-se ao arrolamento do sujeito em uma realidade que o constrange, mesmo que de modo sutil e imperceptível, a se enquadrar em certas predisposições, percebidas como condições sociais.

\footnotetext{
${ }^{5}$ Utilizamos de modo proposital e não redundante os vocábulos atitude e comportamento, pois consideramos as suas designações distintas e adotamos como base a caracterização estabelecida por Alves (2008, p. 57): "por atitude compreende-se uma maneira organizada e coerente de pensar, sentir e reagir em relação a grupos, questões, outros seres humanos ou, mais especificamente, a acontecimentos ocorridos em nosso meio circundante. Trata-se de um dos conceitos fundamentais da psicologia social, por fazer a junção entre a opinião (comportamento mental e verbal) e a conduta (comportamento ativo), indicando o que interiormente estamos dispostos a fazer, ou seja, a predisposição que temos de reagir a estímulos de maneira positiva ou negativa. O comportamento refere-se ao conjunto organizado das operações selecionadas em função das informações recebidas do ambiente através do qual o indivíduo integra suas tendências. Ou seja, designa a mudança, o movimento ou reação de qualquer entidade ou sistema em relação a seu ambiente ou situação".

${ }^{6} \mathrm{Na}$ acepção que propomos, a deliberação não pode ser nem será balizadora para estabelecermos a ocorrência de uma violência interpessoal, porquanto consideramos, como já enunciado, que as relações interpessoais se estabelecem tantas vezes a partir de bases instáveis e abstrusas, nas quais os sujeitos estão vulneráveis a ações e pronunciamentos que divergem desde a intenção até o resultado produzido, podendo violentar outrem mesmo não sendo esse o desejo primário. Além disso, a violência não se restringe à esfera da interação explícita, podendo envolver o plano simbólico, inclusiva ou complementarmente.
} 
Tal perspectiva, de uma abordagem interpessoal e simbólica da violência, confirma-se pela ponderação de Vázquez (2007, p. 377-378):

$\mathrm{Na}$ sociedade baseada na exploração do homem pelo homem, como é a sociedade capitalista atual, a violência não só se mostra nas formas diretas e organizadas de uma violência real e possível, como também se manifesta de um modo indireto, e aparentemente espontâneo, como violência vinculada com o caráter alienante e explorador das relações humanas. Tal é a violência [...] que já não é a resposta a outra violência potencial ou em ato, mas[,] sim[,] a própria essência do regime social. Essa violência surda causa muito mais vítimas que a violência dos organismos coercitivos do Estado.

Ressaltamos, por fim, que a proposta que oferecemos não rompe com a literatura já desenvolvida acerca do tema assédio moral no trabalho, mas busca rever o conceito que normalmente é empregado, apontando suas limitações e propondo uma alternativa conceitual e analítica. Assim, entendemos que a discussão mantém sua relevância se relida à luz das questões e do conceito que ora colocamos.

\section{Metodologia}

Primeiramente, cabe uma descrição do objeto de pesquisa. A organização em questão é uma empresa júnior voltada à consultoria nas áreas de Administração e Economia para empresas de todos os portes, empreendedores, órgãos governamentais e para a sociedade em geral, em sua cidade e sua região. Fazem parte de seu escopo de clientes instituições de renome nacional e internacional e ela é considerada umas das mais, se não a mais, importante empresa de consultoria da região metropolitana em questão. Essa empresa júnior é sediada em uma instituição de ensino superior pública do sudeste brasileiro e conta com cerca de 18 anos de existência. Sua missão é capacitar bacharelandos por meio de experiências que simulem a realidade profissional e de mercado, além de proporcionar a aplicação dos conhecimentos adquiridos durante seus respectivos cursos de graduação. Como indicado na introdução, essa empresa júnior será designada EJ, por questões éticas, tendo em vista resguardar os participantes da pesquisa e a própria instituição.

A pesquisa foi desenvolvida por meio de uma metodologia qualitativa, dada a especificidade das questões que almejamos responder, direcionadas à apreensão em profundidade do "[...] mundo de significados das ações e relações humanas, um lado não perceptível e não captável em equações, médias e estatísticas" (MINAYO, 1996, p. 22).

Dada a importância de uma leitura em profundidade do fenômeno, a estratégia de pesquisa qualitativa adotada foi o estudo de caso, já que consideramos que tal estratégia "[...] é útil para gerar conhecimento sobre características significativas de eventos vivenciados" (MINAYO, 2008, p. 164), visto que estabelece laços entre a acepção e a pertinência de certas circunstâncias-chave.

Optamos, então, pela história oral como método por entender que ela possibilita ao pesquisador recuperar, em cada entrevista realizada, relações simples e complexas em relação à sociedade, ao grupo e ao próprio sujeito, assim como "[...] reconstruir durações emocionais, afetivas, reflexões racionais que se irradiam, se cruzam em determinados momentos num espaço sócio-histórico de determinadas relações sociais" (MARRE, 1991, p. 120), tal como na EJ.

Para tanto, entrevistamos sujeitos que atuaram ou ainda atuam como empresários juniores na EJ. Efetuamos 20 entrevistas de história oral, sendo elas realizadas com 3 membros ativos, 16 ex-membros e 1 excolaborador. As entrevistas de história oral foram realizadas com base em um roteiro semiestruturado, e gravadas em meio digital, a partir do consentimento de cada sujeito de pesquisa. As entrevistas, cujo tempo total de gravação foi de 45 horas e 6 minutos, foram transcritas, então, com o cuidado de resguardar a reprodução fiel dos discursos, evitando cortes e acréscimos, para ser analisadas posteriormente. 
A análise das histórias coletadas deu-se pelo emprego da técnica hermenêutica/dialética, que, para Gomes (1996, p. 77), é uma abordagem na qual "[...] a fala dos atores sociais é situada em seu contexto para melhor ser compreendida. Essa compreensão tem, como ponto de partida, o interior da fala. E, como ponto de chegada, o campo da especificidade histórica e totalizante que produz a fala". A operacionalização da técnica hermenêutica/dialética ocorreu por meio da ordenação e classificação dos dados, seguindo as orientações de Minayo (2008). O procedimento de classificação dos dados subdividiu-se em 4 etapas: 1) leitura horizontal exaustiva dos textos; 2) leitura transversal; 3) análise final; 4) relatório. Além disso, levamos em consideração nessa análise o conceito de violência interpessoal em suas manifestações físicas, discursivas, por atitudes e/ou por comportamentos, conforme definições anteriormente apresentadas.

\section{Análise da violência vivenciada}

Nesse item apresentamos falas que retratam a violência interpessoal vivenciada por meio de violência física, discursiva, por atitudes e/ou por comportamentos. Recordamos, sinteticamente, que violência física refere-se a violações envolvendo o corpo humano; a discursiva causa prejuízo a um sujeito por intermédio da linguagem; a oriunda de atitudes refere-se a afrontas advindas de predisposições de outrem para reagir de maneira negativa; e a oriunda de comportamentos é caracterizada por prejuízos originários de um conjunto de reações que se pode observar em um indivíduo. Vale lembrar, ainda, que a violência simbólica diz respeito ao envolvimento do sujeito em uma realidade opressora, ainda que seja sutil e imperceptível, ou seja, naturalizada. Analisamos, primeiramente, relatos de agressão física. $\mathrm{O}$ primeiro relato nos remete ao período entre 1995 e 1996.

Teve uma situação muito engraçada com uma colega nossa, colega mesmo, que entrou com a gente. E, nesse dia, tinha cinco para a seleção mais ela, que estava num cantinho. Aí, a menina [que era nossa colega] entrou com a mochila e colocou a mochila no colo. Daí, alguém [da EJ] pediu: "empresta-me a sua mochila". Ela: "não". [Esse] alguém: "emprestame a sua mochila". Ela: "não". Ela [alguém da EJ] pegou a mochila dela, tomou a mochila dela. Eu me lembro que isso foi desastroso, porque simplesmente ela perdeu totalmente o chão, ela ficou simplesmente... era outra pessoa. Aí, foi muito mal na entrevista. E a gente sabia que era uma menina muito boa, muito responsável e tudo mais. (Entrevistado 9)

Nota-se que, desde o início da fala, o entrevistado busca suavizar o constrangimento que uma colega sofreu durante processo seletivo realizado pela gestão da $\mathrm{EJ}$, da qual ele participava. Um empresário júnior "arrancou" a mochila de uma candidata, o que denota algo como tomar à força, contrariando a vontade da pessoa. Esta última parte é, inclusive, explicitada por E9, uma vez que sua colega se negou repetidamente a ceder sua mochila. As consequências também foram explicitadas, ou seja, a desestruturação emocional da candidata e o prejuízo em seu desempenho, sendo que o entrevistado a julgava "muito boa".

Outra violência física se passou na EJ entre 1998 e 1999.

Teve um presidente que pegou um livro, bateu na cabeça de um membro e falou assim: "você é burra". Pá! [onomatopeia da batida]. Nós chamamos, conversamos com ele, mostramos. Mas ele se achava muito rigoroso com ele mesmo. A menina acabou saindo da empresa. Ela não ficou. Ela não suportou. A gente disse assim: "primeiro que você não poderia ter feito isso, porque não é um padrão que você tem, você está mudando o seu comportamento". Ele reconheceu o erro, mudou e aprendeu com o erro. Então, a gente viu muitas coisas acontecerem em nível comportamental. Claro, é um processo de crescimento. E esse indivíduo, ele era excelente, foi um dos grandes presidentes que a empresa teve. Mas ele era... Ele como que tinha um rigor com ele mesmo, ele tinha um rigor com as outras pessoas, ele não admitia, entre aspas: "incompetências" ou "negligências" ou "erros". Nisso, ele puniu a pessoa de uma forma errada. Mas ele aprendeu depois. Foi bom. E foi bom para a pessoa [vítima], porque ela viu depois que tinha problemas, enfim. Ela também 
não estava muito internalizada na própria cultura da empresa. E ele estava nervoso. (Entrevistado10)

Essa violência, além de física, também é discursiva. Como se não bastasse o sujeito utilizar-se de sua posição hierárquica para se sentir no direito de bater em uma pessoa, ainda exacerba seu ato agredindo-a verbalmente, a fim de rebaixá-la. Em consequência disso, a estudante saiu da empresa, enquanto o violentador lá continuou, como presidente e sem qualquer punição. $O$ entrevistado em questão tenta justificar as ações de tal presidente dizendo que ele estava nervoso, que depois se arrependeu, aprendeu e que tudo se deveu ao fato de ele ser muito rígido consigo mesmo e com os outros. Entretanto, tais explicações em nada minimizam ou desculpam a situação passada. O presidente foi, então, advertido, mas porque estava mudando seu comportamento, como se esse fosse o núcleo do problema. O fato de E10 sugerir que um padrão de conduta agressiva anterior poderia justificar o comportamento do presidente pode ser entendido como um indício de como ocorrem os mecanismos de naturalização. E, por fim, somos informados de que a vítima internalizou a acepção do violentador, que passou a se considerar corresponsável, porquanto não internalizou a cultura da empresa. Destacamos esse ponto, pois denota uma violência simbólica, tendo em vista a imposição de uma adequação do sujeito à cultura da EJ e a exclusão daqueles que não se submetiam e se submetem, de forma naturalizada.

Agora abordamos casos de violência discursiva. O relato a seguir se refere a situações que ocorreram na EJ entre 2001 e 2002.

Na diretoria, por conta desta cultura da EJ, rolava um quebra-pau mesmo, de bater na mesa, gritar, apontar dedo na cara. Eu vi muito isso lá. E isso me assustou. "Caramba, é assim?". Aquilo foi um baque para mim, eu não esperava que as pessoas levassem tão a sério, vamos dizer assim. Isso me chocou porque eu não esperava isso dentro de uma empresa júnior, não combina, né? (Entrevistado 4)

Observe que o entrevistado explicita esses embates como algo corriqueiro e, quase, normal na relação que se estabelecia entre os diretores. Tal comportamento, inclusive, gera espanto nele, uma vez que parece esperar menor extremismo por parte daqueles que estavam em uma posição hierárquica superior e que, desse modo, deveriam ter maior maturidade para encarar os eventos. Ele enfatiza, também, que aquela era uma empresa júnior, na qual se espera que o preceito fundamental seja o aprendizado e, assim, que haja maior tolerância com o erro.

Houve apenas esse relato de violência exclusivamente discursiva. Nos demais, ela foi associada a comportamentos diversos. Assim, serão tratados em conjunto com a violência pautada por comportamentos. As passagens subsequentes retratam violência gerada por atitudes.

Em 2004 ocorreram os constrangimentos descritos a seguir, os quais são típicos indicativos de predisposição e perseguição.

Depois, eu fui saber que eu fui alocada no departamento de finanças, mas que o departamento ficou muito revoltado. Ninguém me queria lá. Os diretores aceitaram, o novo e o antigo, mas os membros, não. $\mathrm{O}$ departamento de finanças era um departamento pesadinho, o que eu entrei. E eram pessoas que o tempo inteiro tentavam me atrapalhar. Pra ser sincera, eles ficavam o tempo inteiro tentando me mostrar que eu não era capaz ou que eu não conseguiria ou me dando coisas demais, sendo supercobrada. Coisas do tipo... Havia algumas atividades, por exemplo, o departamento de finanças tinha que comprar as coisas para suprir a empresa, e a gente fazia um rodízio das atividades. E, aí, teve um dia que faltou copo na EJ. Sabe, isso foi motivo para uma reunião de departamento e todo mundo falando que isso não podia, que o copo não podia faltar, que isso era uma coisa de extrema importância. "Imagina uma multinacional faltando copo descartável". Eles transformavam um erro meu (todo mundo erra, né?) em uma coisa gigantesca, em uma coisa enorme, tipo: "você errou!". Era essa a minha percepção, por mais que eu tentasse me esforçar, eu não 
conseguia fazer o que eles estavam querendo. Hoje, depois que saí da EJ, é que eu comecei a entender o que estava acontecendo. É porque eles não estavam me querendo lá dentro, não é porque eu deixei de comprar copo. Era uma birrazinha que eles tinham. Eles achavam que eu não era apropriada para o departamento. Com o tempo, eu fui conquistando eles, pessoalmente, e essa perseguição se transformou em: "a gente quer que você seja uma pessoa boa, porque a gente acredita em você”. (Entrevistada 11)

A alocação da entrevistada no departamento de finanças da organização estudada, segundo seu relato, é marcada por uma sucessão de eventos destinados a impeli-la a abandonar a EJ. Tal postura decorre da suspeita ou negação de sua capacidade profissional, independentemente do esforço empreendido por E11. Em princípio, tais sujeitos utilizam artifícios descabidos e que são supervalorizados para alegar uma não competência da entrevistada. Com o transcorrer do tempo, a afetividade se instaura nas relações e os reprodutores da violência passam a justificá-la com o subterfúgio da ensinadela, obliterando sua percepção.

Ao longo de 2004, a situação pouco se alterou, tanto nas mediações departamentais quanto nas questões políticas.

Picuinha. Tentar fazer parecer o que a outra fez ser pior. Ou tentar sabotar o trabalho do outro dentro do departamento, por politicagem mesmo. Política. Política mesmo, de ter que tentar ganhar votos em uma eleição. Aconteceu de gente tentar angariar voto mesmo. De falar mal do concorrente e tentar puxar... E chegar num outro grupinho e também tentar se ajeitar no outro grupinho. Mas foi altamente punido por nós. A gente chamou a atenção, falamos que sabíamos de tudo. E a pessoa murchou e tomou as atitudes dela. (Entrevistado18)

Como expressa o Entrevistado 18, algumas relações na EJ encontravam-se permeadas pela competição. O entrevistado tem o cuidado de não entrar em muitos detalhes para não denunciar a quem se referia. Mas informa que ocorreram, quando ele estava na diretoria, disputas pouco leais em determinado departamento por interesse político, nas quais houve sabotagem e tentativas de prejudicar o trabalho alheio, uma violência que, ao menos dessa vez, foi punida e liquidada.

Por fim, tratamos da violência interpessoal, fruto de comportamentos. A primeira delas data de 2002 .

Eu fiz um texto que ia entrar no relatório final [de um projeto de consultoria]. Isso marcou pro resto da vida. Extremamente pesquisado, visto e revisto por professor, autorizado: "Não, está legal, é isso mesmo". O membro mais experiente do projeto olhou e falou: "beleza, é isso aí". O outro colaborador consultor olhou e gostou também. E outra pessoa que estava também no projeto, pegou, leu e falou: "Não, eu não gostei não". E eu: "pô, mas todo mundo gostou". E ela: "Não". Aí, marcou tudo com shift e apagou tudo. Ninguém fez nada, porque só estava eu e ela e já estava feito. Mas ninguém aprovou, é claro. (Entrevistado18)

A descrição do Entrevistado 18 explicita o desrespeito de um membro da EJ para com o trabalho apresentado por um colaborador consultor. Aquele rejeitou o texto do outro, sem ao menos lhe conceder uma justificativa ou oportunidade de revisão, não obstante ser o intuito da vinculação de um colaborador a um projeto o tirocínio desse sujeito. Em tal circunstância, destacam-se, além da imposição pelo membro de sua avaliação arbitrária do colaborador, a condescendência ou resignação do restante da equipe de projeto diante do fato, que nada fizeram, mesmo tomando conhecimento do ocorrido.

A passagem imediata e final trata de desencontros e mentiras e remete a 2003.

Entrei para o departamento de Marketing, fiquei lá umas duas gestões, eu acho. Daí, surgiu uma vaga pra Qualidade. Ia ter uma reunião geral e eu soube umas 3 ou 2 horas antes: "V, vai ter uma vaga na Qualidade, tal menino vai sair e tal...”. Aí, eu entrei em pânico. É a 
oportunidade que eu tenho de ir para a Qualidade e tal. Aí, eu tentei falar com a "C", que era a minha diretora na época, e ela com prova [na faculdade], e ela não chegava. E eu desesperada, porque eu queria aproveitar a oportunidade. Aí, enfim, eu conversei com a diretora presidente da época, que era a "F": "Fiquei sabendo que surgiu esta vaga, eu tenho interesse nela, o que eu faço, não sei o que...”. As coisas se atropelaram pela minha ânsia e tal. [...] E, aí, ela chamou a Qualidade e falou: "a Entrevistada 20 está com interesse e tal, o que você acha?". "Ah, beleza e tal". Aí comentaram com a minha diretora antes da reunião: "Ah, a Entrevistada 20 quer ir para a qualidade, falou que surgiu vaga e tal. E a diretora gostou da ideia". Isso não foi anunciado, mas gerou um "furdunço". A minha diretora não gostou. Só que ela não gostou e, aí, ela não teve uma postura muito profissional na época. Fez o departamento todo virar a cara pra mim, passou a situação da maneira que ela estava vendo. Eu não sei porque aconteceu aquilo, mas chegou no ouvido de todo mundo assim... E, aí, a presidente mentiu, falou que eu tinha - olha bem, vê se tem nexo - que eu cheguei para ela dizendo que a minha diretora já tinha aprovado. Foi uma confusão, uma confusão, que, na reunião de diretoria, eu tremia de raiva, mas eu falei tudo que eu queria. Eu virei para ela e falei: "F, você é mentirosa. Você está mentindo, eu não agi assim. Posso ter feito isso e isso errado, mas isso é mentira sua. Se você não quer assumir, o problema é seu". Mas eu fui assim, tremendo. Já viu falar isso com a diretoria? Mas isso podia ir parar na Justiça, mas só que o injustiçado ia abaixo... [...] E foi aí que eu tive o atrito, porque foi assim, em parte, foi para me tirar, para me culpar. Foi assim, de fazer reunião e falar comigo: "eu acho que ela não deve continuar, manda ela embora". Eu falei: "gente, vocês decidem o que vocês quiserem. Eu posso ter agido na ânsia, naturalmente que foi errado. Eu falei com a diretora presidente e eu não respeitei a hierarquia. Mas foi uma coisa de boa fé, não houve a menor má intenção, de magoar e de passar por cima de ninguém”. Eles acharam que eu articulei, assim, muito. E aquilo foi um baque pra mim, me espezinharam um pouco. O pessoal todo do Marketing não falar comigo, todo mundo me ignorar dentro da EJ. Mas, aí, resolveram me deixar continuar e eu fiquei mais um semestre, por aí, e acabei saindo. Mas, aí, ficou tudo bem e eu fiquei lá mais 6 meses, na Qualidade. (Entrevistada 20)

A violência patente no caso descrito caracteriza-se pelo apego à hierarquia. A entrevistada foi triplamente violentada. Primeiro, pela sua diretora, que a caluniou diante dos demais membros de seu departamento sem ao menos consultá-la a respeito dos fatos; pelos seus colegas de departamento, que também aderiram ao discurso alheio e posicionaram-se contra a Entrevistada 20; E pela presidente da empresa, que deturpou o ocorrido, livrando-se de qualquer responsabilidade ao culpabilizar a entrevistada. Contra o esperado, a entrevistada não se conformou nem consentiu com o seu possível desligamento, desafiando a caluniadora, mesmo sendo ela a presidente. Contudo, a Entrevistada 20 relevou toda a situação ("aí, ficou tudo bem”), conformou-se com a violência sofrida e permaneceu na empresa por mais 6 meses.

\section{Conclusões}

O objetivo deste artigo teórico/empírico foi analisar a violência interpessoal vivenciada por sujeitos que atuam ou atuaram profissionalmente em uma empresa júnior, na EJ. Para tanto, teoricamente, recuperamos as bases da discussão proposta, perpassando as concepções iniciais sobre mobbing até a evolução do conceito de assédio moral no trabalho. Apresentamos, então, as ideias dos principais autores brasileiros que tratam do tema. Na sequência, estabelecemos algumas críticas à acepção corrente no estudo do assédio moral, sendo elas, em suma: a pouca atenção dada à percepção dos sujeitos quanto àquilo que consideram ou relatam desapercebidamente, como violência; a necessidade da recursividade para caracterizar o assédio moral; a limitação de seus impactos à esfera do trabalho; a qualificação do assediador como perverso narcisista; a premeditação do assediador; a posição passiva do assediado, entre outros aspectos. A partir de tais apreciações, elaboramos um conceito para violência interpessoal, que não se restringe a considerar a intencionalidade do sujeito, sem, contudo, ignorar o mérito e romper com todo o conteúdo desenvolvido pelos estudiosos do assédio moral no trabalho. 
Empiricamente, apresentamos e analisamos determinadas histórias de violência interpessoal, em suas diversas manifestações: física, discursiva, por atitude e por comportamento. Não esgotamos o conjunto de relatos obtidos, contudo, afirmamos que eles não foram tão numerosos quanto esperávamos. Ambas as afirmações são feitas comparando o volume de dados empíricos arrolados como violência interpessoal e violência simbólica (estas já abordadas em outro trabalho) e ao realce com que elas se apresentam aos pesquisadores em geral.

A concisão dos dados empíricos obtidos na pesquisa que desenvolvemos se deve à escassez de menções ou insinuações envolvendo a ocorrência de violência interpessoal. Isso, possivelmente, por ser a interpretação dessa violência mais evidente e, portanto, suas experiências são claramente entendidas como tais. A resistência em relatar violência interpessoal pode ser atribuída ao receio de macular a imagem da EJ, pela qual tantos zelam, mesmo que por razões ambíguas. Isso fica ainda mais patente quando notamos não haver qualquer menção ou insinuação de uma violência interpessoal por parte dos entrevistados que dela se desligaram há pouco tempo ou que nela ainda estão. Talvez a necessidade de enquadrar-se seja tamanha que os indivíduos não se permitem perceber nem a violência mais evidente. E aqueles que já se desligaram da empresa, normalmente, quando relatam alguma violência interpessoal da qual foram vítimas, terminam dizendo que "depois ficou tudo bem" e que permaneceram na empresa. Parece que, mesmo passado algum tempo, eles ainda anuem com a violência sofrida em prol do dito aprendizado que obtiveram.

Fica claro, em várias oportunidades, como são velados os conflitos interpessoais na EJ. Muitos entrevistados, ex-membros da EJ, relataram que não presenciaram embates, mas estão certos de que eles ocorreram, por isso, não puderam descrevê-los. De qualquer modo, supomos que aqueles que lá se encontram estejam enquadrados. Caso contrário, logo sairiam por ou contra sua vontade. Acreditamos que qualquer violência explícita deve mesmo ser evitada. A consciência de manifestações explícitas de violência na organização poderia colocar a ordem em risco. Desejável é aquela "violenciazinha imperceptível" e insidiosa, que modela o homem de acordo com os preceitos da ideologia da administração, preparados para que o mundo administrado seja aceito e aperfeiçoado, também conhecidos por violência simbólica.

Percebemos que a violência relatada é, na maioria das vezes, naturalizada pelas próprias vítimas e pelo corpo social como decorrência de uma práxis tida como necessária para a incorporação do sujeito entre os elegíveis a economicamente bem-aventurados.

Destacamos, ainda, que, ao término da pesquisa desenvolvida, deparamo-nos com o imbricamento das categorias violência interpessoal e violência simbólica. Ousaríamos indicar a inseparabilidade de tais categorias, uma vez que a violência interpessoal acaba por se conformar ou por refletir a realidade constituída pela violência simbólica. Destarte, não é possível refletir sobre a violência interpessoal assinalada sem uma associação com o âmbito simbólico que a legitima e perpetua. Por essa razão, tantas vezes tivemos de aludir ao campo do simbólico e à sua correlata violência.

Julgamos interessante apontar, por fim, algumas propostas para futuros trabalhos. Há necessidade de novas pesquisas empíricas que abordem tal apreensão de violência interpessoal vivenciada nos mais variados ambientes de trabalho. Ademais, discussões, críticas e revisões da proposta e da análise que concebemos seriam proveitosas, pois somente desse modo o conhecimento evolui.

\section{Referências}

ALVES, M. R. Reflexões sobre atitude, comportamento e oftalmologia. Revista Brasileira de Oftalmologia, v. 67, n. 2, p. 57-58, abr. 2008.

CATLEY, B. Philosophy: the luxurious supplement of violence? In: INTERNATIONAL CRITICAL MANAGEMENT CONFERENCE, 3, 2003, Lancaster. Proceedings... Lancaster: CMS, 2003. 
. Workplace violence and the forging of management and organization history. In: INTERNATIONAL CRITICAL MANAGEMENT CONFERENCE, 4, 2005, Cambridge. Proceedings... Cambridge: CMS, 2005.

DEJOURS, C. Uma nova visão do sofrimento humano nas organizações. In: CHANLAT, J. F. (Org.). O indivíduo na organização: dimensões esquecidas. São Paulo: Atlas, 1996. 149-173 p.

FREITAS, M. E. Assédio moral e assédio sexual: faces do poder perverso nas organizações. RAE: Revista de Administração de Empresas, v. 41, n. 2, p. 8-19, abr./jun. 2001.

Quem paga a conta do assédio moral no trabalho? RAE Eletrônica, v. 6, n. 1, art. 5, jan./jun. 2007.

; HELOANI, R.; BARRETO, M. Assédio moral no trabalho. São Paulo: Cengage Learning, 2008.

GOMES, R. A análise de dados em pesquisa qualitativa. In: MINAYO, M. C. S. Pesquisa social: teoria, método e criatividade. 6. ed. Petrópolis, RJ: Vozes, 1996. 67-80 p.

HELOANI, R. Assédio moral: um ensaio sobre a expropriação da dignidade no trabalho. RAE Eletrônica, v. 3, n. 1, art. 10, jan./jun. 2004.

HIRIGOYEN, M. F. Assédio moral: a violência perversa no cotidiano. 6. ed. Rio de Janeiro: Bertrand Brasil, 2003.

Mal-estar no trabalho: redefinindo o assédio moral. 2 ed. Rio de Janeiro: Bertrand Brasil, 2005.

LA BOÉTIE, E. Discurso sobre a servidão voluntária. Lisboa: Antígona, 1986.

LEYMANN, H. The content and development of mobbing at work. European Journal of Organizational Psychology, v. 5, n. 2, p. 165-184, 1996.

MARRE, J. L. História de vida e método biográfico. Cadernos de Sociologia, v. 3, n. 3, p. 89-141, jan./jul. 1991.

MINAYO, M. C. S. Ciência, técnica e arte: o desafio da pesquisa social. In: MINAYO, M. C. S. (Org.). Pesquisa social: teoria, método e criatividade. 6. ed. Petrópolis, RJ: Vozes, 1996. 9-29 p.

. O desafio do conhecimento: pesquisa qualitativa em saúde. São Paulo: Hucitec, 2008.

OLIVEIRA, F. M. Subjugação no ambiente de trabalho: uma análise sobre o fenômeno do assédio moral em uma organização militar. In: ENCONTRO DE ESTUDOS ORGANIZACIONAIS, 4, 2006, Porto Alegre. Anais... Porto Alegre: Anpad, 2006. 1 CD-ROM.

PELI, P.; TEIXEIRA, P. Assédio moral: uma responsabilidade corporativa. São Paulo: Ícone, 2006.

VÁZQUEZ, A. S. Filosofia da práxis. São Paulo: Clacso, 2007. 